\title{
Systematic review and meta-analysis on the utility of Interferon-gamma release assays for the diagnosis of Mycobacterium tuberculosis infection in children: a 2013 update
}

\author{
S Sollai ${ }^{\dagger}, \mathrm{L}$ Galli ${ }^{\dagger}, \mathrm{M}$ de Martino ${ }^{*}{ }^{\dagger}$, E Chiappini $^{*+}$
}

\begin{abstract}
Background: Previous meta-analyses regarding the performance of interferon-gamma release assays (IGRAs) for tuberculosis diagnosis in children yielded contrasting results, probably due to different inclusion/exclusion criteria.

Methods: We systematically searched PubMed, EMBASE and Cochrane databases and calculated pooled estimates of sensitivities and specificities of QuantiFERON-TB Gold In Tube (QFT-G-IT), T-SPOT.TB, and tuberculin skin test (TST). Several sub-analysis were performed: stratification by background (low income vs. high income countries); including only microbiological confirmed TB cases; including only studies performing a simultaneous three-way comparison of the three tests, and including immunocompromised children.

Results: Overall, 31 studies (6183 children) for QFT-G-IT, 14 studies (2518 children) for T-SPOT.TB and 34 studies (6439 children) for TST were included in the analyses. In high income countries QFT-G-IT sensitivity was 0.79 (95\% IC: $0.75-0.82)$ considering all the studies, 0.78 (95\%Cl:0.70-0.84) including only studies performing a simultaneous three-way comparison and 0.86 (95\% IC 0.81-0.90) considering only microbiologically confirmed studies. In the same analyses T-SPOT.TB sensitivity was 0.67 (95\%IC 0.62-0.73); 0.76 (95\%Cl: 0.68 to 0.83 ); and 0.79 (95\%IC 0.69-0.87), respectively. In low income countries QFT-G-IT pooled sensitivity was significantly lower: 0.57 (95\%lC:0.52-0.61), considering all the studies, and 0.66 (95\%lC $0.55-0.76$ ) considering only microbiologically confirmed cases; while T-SPOT.TB sensitivity was 0.61 (95\%IC 0.57-0.65) overall, but reached 0.80 (95\% IC 0.73-0.86) in microbiologically confirmed cases. In microbiologically confirmed cases TST sensitivity was similar: 0.86 (95\%lC 0.79-0.91) in high income countries, and 0.74 (95\%lC 0.68-0.80) in low income countries. Higher IGRAs specificity with respect to TST was observed in high income countries (97-98\% vs. 92\%) but not in low income countries (85-93\% vs. 90\%).
\end{abstract}

Conclusions: Both IGRAs showed no better performance than TST in low income countries.

\section{Background}

Diagnosis of paediatric tuberculosis infection remains a challenging issue. Tuberculin skin test (TST) has several limitations: sensitivity may be influenced by the child's age and immunologic status, bacille Calmette-Guérin (BCG) vaccination or non-tuberculosis mycobacteriuminfections; in case of repeated tests a booster effect can occur and a double access to a health care facility is

\footnotetext{
*Correspondence: maurizio.demartino@unifi.it; elena.chiappini@unifi.it † Contributed equally

Department of Health Sciences, Meyer Children University Hospital, University of Florence, Florence, Italy
}

needed. Nevertheless, infiltrate measurement may be operator-dependent [1-4]. Interferon gamma release assays (IGRAs), including the commercially available assays QuantiFERON ${ }^{\circledR}$-TB Gold (QFT-G; Cellestis, Australia), QuantiFERON ${ }^{\circledR}$-TB Gold In-Tube (QTF-GIT, Cellestis, Australia), and the T-SPOT TB (T-SPOT ${ }^{\circledR}$, Oxford Immunotec Ltd. UK), have been extensively used for the diagnosis of tuberculosis infection in adults.

IGRAs allow detection of circulating T-cells responsive to specific Mycobacterium tuberculosis antigens, which are absent in BCG and many non-tuberculosis mycobacteria, and displayed similar sensitivity and higher specificity than 
TST in adults (table 1) [5-12]. However, IGRA performance in paediatric populations is still under debate and caution is recommended for their use and interpretation in children [13]. Some authors reported a sub-optimal IGRA sensitivity in children [14], but this finding has not been confirmed by others [8]. Five meta-analyses have previously assessed IGRA sensitivity and specificity in children but reported pooled estimates largely differ (Table 1) [1,5,9-11]. Such discordances may be due to different inclusion/exclusion criteria and, thus, different characteristics of the study populations (i.e. proportion of immunocompromised/HIV infected and/or young children included). The setting is also relevant. IGRA performance is influenced by the child's immunologic status, which, in turn, may be impaired by several conditions commonly observed in low income countries, such as malnutrition, HIV-infection, and elminthiasis [1-3]. Hereby, we report results of an updated meta-analysis regarding IGRA performance in children, focusing on settings, age, and immunologic status of the study children.

\section{Methods}

A literature search using multiple keywords and standardized terminology in Medline, EMBASE and Cochrane databases dating back to their inception up to and through June 7th, 2013, as summarized in Additional file 1, appendix 1. Inclusion and exclusion criteria, extraction of data and assessment of study quality are reported in Additional file 1. In particular only studies evaluating QuantiFERON $^{\circledR}$-TB Gold In-Tube (QTF-G-IT, Cellestis, Australia), and/or T-SPOT TB (T-SPOT ${ }^{\circledR}$, Oxford Immunotec Ltd. UK) in comparison to TST were included while studies using QFT-G were excluded.

\section{Statistical methods}

For each included study, we computed and calculated sensitivity or specificity (and 95\% CIs) and summarized the results in forest plots. Random-effects meta-analysis was performed using MetaDiSc ${ }^{\circledR}$, Meta-analysis of Diagnostic and Screening tests, Version 1.4 [15]. Studies were weighted by total sample size to pool estimates of sensitivity and specificity across the studies. Chi-square test was used to evaluate the presence of statistically significant heterogeneity across studies, whose variance proportion attributable to between studies heterogeneity was expressed calculating the $\mathrm{I}^{2}$ statistic.

\section{Results}

For the analysis of sensitivity, 31 studies (20 conducted in high income countries and 11 in low income countries) for QFT-G-IT, including 6183 children [3,16-44], 14 studies (9 conducted in high income countries and 5 conducted in low income countries for T-SPOT.TB including 2518 children $[10,14,16,18,19,22,23,37,39,45-48,50]$ and

Table 1 Sensitivity and specificity of Interferon-gamma release assays (IGRAs) and tuberculin skin test (TST) in the previous published meta-analyses [1,5-12]

\begin{tabular}{|c|c|c|c|c|c|c|}
\hline & TST & QFN-G-IT & T-SPOT.TB & Population & $\begin{array}{l}\text { Number of } \\
\text { studies } \\
\text { considered }\end{array}$ & $\begin{array}{l}\text { Author, year of } \\
\text { publication }\end{array}$ \\
\hline \multirow[t]{9}{*}{ Sensitivity } & $0.70(95 \% \mathrm{Cl} 0.67-0.72)$ & $0.81(95 \% \mathrm{Cl} 0.78-0.89)$ & $0.84(95 \% \mathrm{Cl} 0.81-0.87)$ & Adults & 124 & Diel, 2010 \\
\hline & $0.77(95 \% \mathrm{Cl} 0.71-0.82)$ & 0.78 (95\% Cl 73-82) & $0.90(95 \% \mathrm{Cl} 0.86-0.93)$ & Adults & 20 & Pai, 2008 \\
\hline & & $0.80(95 \% \mathrm{Cl} 0.75-0.91)$ & 0.81 (95Cl 0.78-0.84) & Adults & 27 & Sester, 2010 \\
\hline & $0.80(95 \% \mathrm{Cl} 0.70-0.90)$ & $0.83(95 \% \mathrm{Cl} 0.75-0.92)$ & $0.84(95 \% \mathrm{Cl} 0.63-1.00)$ & Children & 32 & Mandalakas, 2011 \\
\hline & $0.71(95 \% \mathrm{Cl} 0.67-0.75)$ & $0.70(95 \% \mathrm{Cl} 0.65-0.75)$ & $0.62(95 \% \mathrm{Cl} 0.57-0.67)$ & Children & 16 & Sun, 2011 \\
\hline & $0.82(95 \% \mathrm{Cl} 0.72-0.93)$ & 0.79 (95\%Cl 0.70-0.89) & $0.74(95 \% \mathrm{Cl} 0.59-0.90)$ & Children & 11 & Chiappini, 2012 \\
\hline & & 0.77 (95\%Cl 0.64-0.73) & & $\begin{array}{l}\text { Adults and } \\
\text { Children }\end{array}$ & 11 & Dheda, 2009 \\
\hline & & 0.66 (95\%।C 0.53-0.78) & & Children & 6 & Machingaidze, 2011 \\
\hline & $0.71(95 \% \mathrm{Cl} 0.65-0.74)$ & $0.76(95 \% \mathrm{Cl} 0.70-0.83)$ & $0.88(95 \% \mathrm{Cl} 0.81-0.95)$ & $\begin{array}{l}\text { Adults and } \\
\text { Children }\end{array}$ & 58 & Menzies, 2007 \\
\hline \multirow[t]{7}{*}{ Specificity } & & $0.99(95 \% \mathrm{Cl} 0.98-1.00)$ & $0.86(95 \% \mathrm{Cl} 0.81-0.90)$ & Adults & 124 & Diel, 2010 \\
\hline & $0.59(95 \% \mathrm{Cl} 0.46-0.73)$ & $0.96(95 \% \mathrm{Cl} 94-98)$ & $0.93(95 \% \mathrm{Cl} 0.86-1.00)$ & Adults & 20 & Pai, 2008 \\
\hline & & $0.82(95 \% \mathrm{Cl} 0.70-0.91)$ & $0.82(95 \% \mathrm{Cl} 0.78-0.86)$ & Adults & 27 & Sester, 2010 \\
\hline & $0.85(95 \% \mathrm{Cl} 0.69-1.00)$ & $0.91(95 \% \mathrm{Cl} 0.78-1.00)$ & $0.94(95 \% \mathrm{Cl} 0.87-1.00)$ & Children & 32 & Mandalakas, 2011 \\
\hline & $0.56(95 \%$ Cl $0.50-0.61)$ & $1.00(95 \% \mathrm{Cl} 0.84-1.00)$ & $0.90(95 \% \mathrm{Cl} 0.86-0.93)$ & Children & 16 & Sun, 2011 \\
\hline & $0.83(95 \% \mathrm{Cl} 0.74-0.92)$ & $0.95(95 \% \mathrm{Cl} 0.93-0.97)$ & $0.96(95 \% \mathrm{Cl} 0.95-1.00)$ & Children & 8 & Chiappini, 2012 \\
\hline & $0.66(95 \% \mathrm{Cl} 0.46-0.86)$ & $0.97(95 \% \mathrm{Cl} 0.96-0.99)$ & $0.92(95 \% \mathrm{Cl} 0.86-0.99)$ & $\begin{array}{l}\text { Adults and } \\
\text { Children }\end{array}$ & 58 & Menzies, 2007 \\
\hline
\end{tabular}


34 studies (18 studies conducted in high income countries and 16 studies conducted in low income countries) for TST including 6439 children [14,17-35,37-43,45-47,49,50] were included.

The specificity analysis included 17 studies, overall including 3844 children (11 conducted in high income countries and 6 in low income countries) using QFT-G-IT [16-22,24-27,30,32,34,37,43], 9 studies overall including 1296 children $(6$ conducted in high income countries and 3 in low income countries) using T-SPOT.TB $[16,18,19$, $22,23,45,46,48,49]$, and 17 studies overall including 3548 children (10 conducted in high income countries and 7 conducted in low income countries) using TST [17-23, 25-27,30,32,34,37,45-47], as summarized in Figure 1.

\section{Pooled IGRAs and TST sensitivity and specificity in high and low income countries}

Considering the whole study population, significantly higher sensitivities of QFT-G-IT and TST in high- than in low-income countries were observed, with no difference between them, while T-SPOT.TB sensitivity was particularly low in both settings $(0.67$ [95\%IC 0.62-0.73] in high income countries, and 0.61 [95\% IC 0.57-0.65] in low income countries) (Figures 1, 2, 3, 4, 5, 6).

In particular, QFT-G-IT sensitivity was 0.79 (95\%IC: $0.75-0.82$ ) in high income countries, and 0.57 (95\%IC $0.52-0.61$ ) in low income countries, and TST pooled sensitivity was 0.78 (95\% IC 0.74-0.82) in high income countries, and 0.67 (95\%IC 0.64-0.70) in low income countries.

Specificity of the three test was similar in low income countries while both QFT-G-IT and T-SPOT.TB displayed higher specificity than TST in high income countries. In particular, QFT-G-IT specificity was 0.97 (95\%IC 0.960.98 ) in high income countries, and 0.85 (95\%IC 0.82-0.88) in low income countries. T-SPOT.TB pooled specificity was 0.98 (95\% IC 0.96-0.99) in high income countries, and 0.93 (95\%IC 0.87-0.96) in low income countries. TST specificity was 0.92 (95\%IC 0.89-0.93) in high income countries, and 0.90 (95\%IC 0.87-0.92) in low income countries.

\section{Sub-analysis for sensitivity including only microbiologically confirmed cases}

Data regarding microbiologically confirmed cases were available in 16 studies (11 studies conducted in high income countries and 5 studies conducted in low income countries), overall including 3689 children for QFT-G-T $[3,14,17,19,20,22,24,26-29,32,34,37,40,44]$, 9 studies (4 conducted in high income countries and 5 conducted in low income countries), including 2013 children for T-SPOT. TB [14,19,22,45-50], and 17 studies (10 studies conducted in high income countries and 7 studies conducted in low income countries), including 4494 children for TST $[3,14,17,19,20,22,24,26,29,32,37,40,45,47,49,50]$.
In this analysis sensitivity of the three test was similar (0.81 (95\%CI: 0.76-0.85) for QFT-G-IT, 0.80 (95\%CI: 0.740.84 ) for T-SPOT.TB, and 0.79 (95\%CI: 0.75-0.83) for TST.

A sub-analysis in studies conducted in high income and low income countries was performed. In high income countries sensitivity of the three test was confirmed to be similar but IGRAs performance in low income countries was suboptimal. QFT-G-IT pooled sensitivity was 0.86 (95\%IC: $0.81-0.90)$ in high income countries but only 0.66 (95\%IC: 0.55-0.76) in low income countries. Even when excluding studies including HIV-infected children, QFT-G-IT pooled sensitivity in low income countries reached only 0.68 (95\%IC: $0.55-0.76$ ).

T-SPOT.TB pooled sensitivity was 0.79 (95\%IC: $0.69-$ 0.87 ) in high income countries, and 0.80 (95\%IC 0.73-0.86) in low income countries. TST sensitivity was 0.86 (95\%IC 0.79-0.91) in high income countries, and 0.74 (95\%IC 0.680.80 ) in low income countries (table 2).

\section{Sub-analysis conducted including only studies performing a simultaneous three-way comparison in the same children (QFT-G-IT; T-SPOT.TB; TST)}

Six of the available studies, including 618 children, evaluated all three tests simultaneously in the same children $[18,19,22,23,37,39]$. All these studies were performed in high income countries. The meta-analytic estimate for sensitivity was 0.78 (95\%CI: 0.70-0.84) for QFT-G-IT; 0.76 (95\%CI: 0.68-0.83) for T-SPOT.TB, and 0.85 (95\%CI: 0.78-0.91) for TST. The meta-analytic estimate for specificity was 0.97 (95\%CI: 0.93-0.99) for QFT-G-IT, 0.97 (95\% CI: 0.93-0.99) for T-SPOT.TB, and 0.84 (95\%CI: 0.79-0.89) for TST (table 2).

\section{Sub-analysis in immunocompromised/HIV-infected children populations}

Overall, 11 studies have assessed utility of IGRAs in paediatric populations including HIV infected children $[3,34,43,50,52-58]$. However, three of them were excluded because the used tests were the in house-ELISPOT [52,55] and the QFT-G not in-tube assay [58]. In five studies utility of IGRAs in immunocompromised children was evaluated as a screening for LTBI with no case of active TB disease included [53-57], and concordance between tests was evaluated. All the results suggest that due to high rates of discordant and indeterminate results in this population, IGRAs should be interpreted with caution and represent tools of little help for TB infection management for immune-compromised children both in high- and low- prevalence settings [53-57].

Complete data for a specific subgroup-analysis were available in four studies $[3,34,43,50]$. Haustein and colleagues included in their analysis immunocompromised children with several different pathologic conditions, 


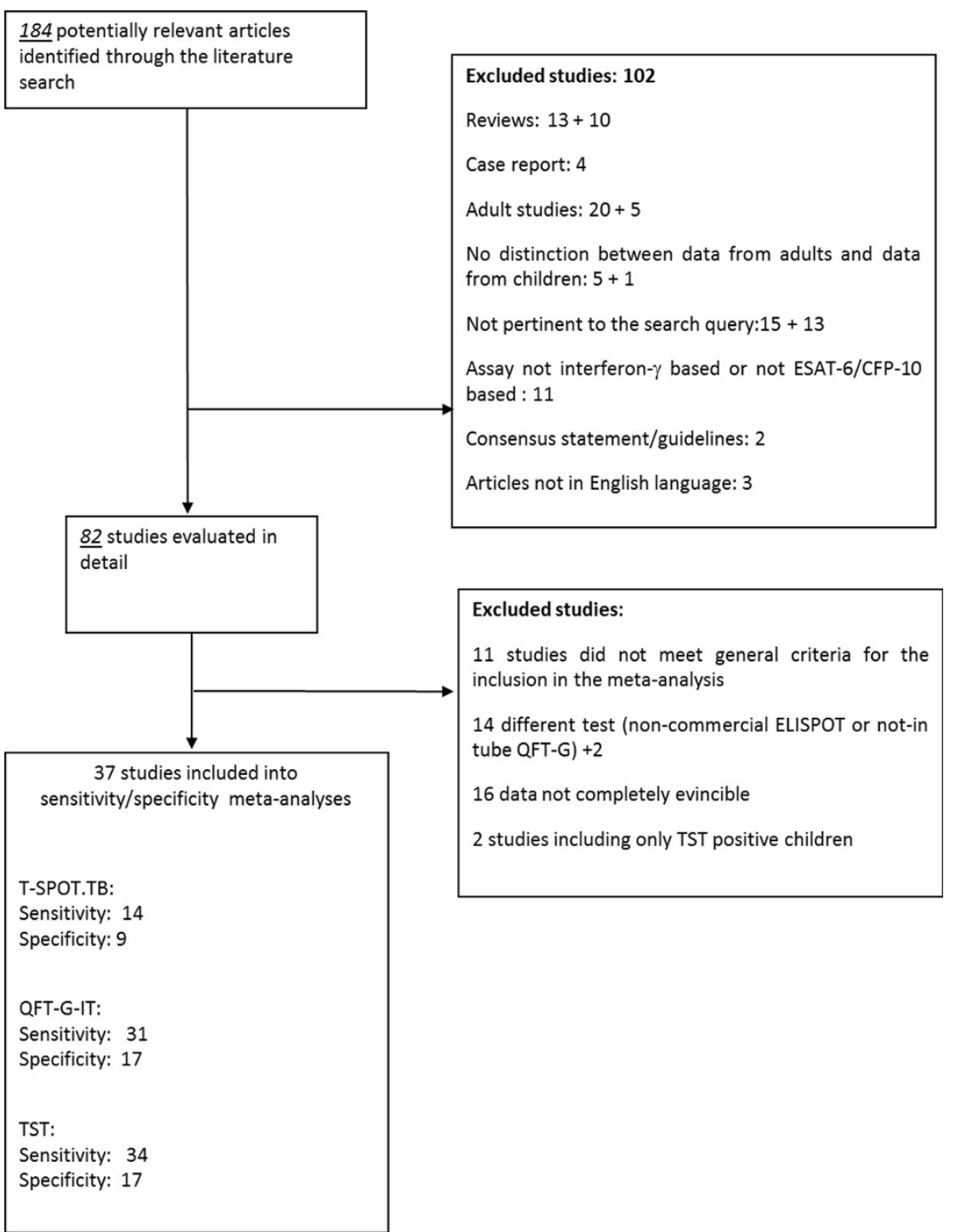

Figure 1 Selection of studies for the meta-analysis. *Inclusion/exclusion criteria as reported in the text and in additional file 1.

including malignancies [3]. In three studies utility of QFT-G-IT was compared to TST [3,34,43], while Ling and colleagues compared T-SPOT.TB to TST [50].

The meta-analytic estimate for sensitivity was very low and similar for QFT-G-IT and T.SPOT.TB: 0.47 (95\%CI: 0.38-0.55) for QFT-G-IT and 0.54 (95\%CI:0.49-0.59) for TST. The meta-analytic estimate for specificity was not performed since only data from 2 studies were available $[34,43]$. Meta-analytic estimate for sensitivity and specificity for T-SPOT.TB was not performed due to lack of data. In the only study available, Ling and colleagues assessed the incremental value of T-SPOT.TB over and above patient characteristics and conventional tests in 491 smear-negative children from two hospitals in Cape Town, South Africa, founding that cough longer than 2 weeks, fever longer than 2 weeks, night sweats, malaise, history of household contact and HIV status were the most important predictors of culture-confirmed TB and concluding that T-SPOT.TB did not have added value beyond clinical data and conventional tests for diagnosis of TB disease in smear-negative children in a high-burden setting [50].

\section{Studies with children populations aged $\leq \mathbf{5}$ years}

Six studies, including 1733 children, included exclusively children aged $\leq 5$ years $[19,28,30,42,59,60]$. In particular, Detjen and colleagues evaluated in 2007 the diagnostic accuracy of TST and 2 IGRAs in a cohort of 73 children (median age: 39 months); comparing 28 children with bacteriologically confirmed TB with children without TB (23 with bacteriologically confirmed non-tuberculous mycobacterial lymphadenitis and 22 with other non-mycobacterial respiratory tract infections) [19]. Specificity of QFT- 


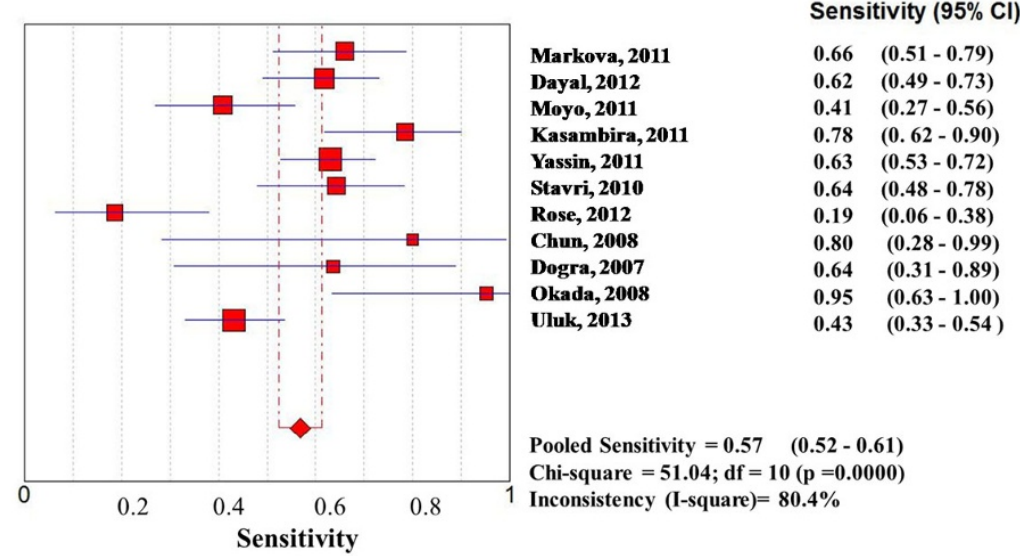

Figure 2 Forest plot of sensitivity of QuantiFERON-TB Gold In Tube (QFT-G-IT) in low-income countries. The squares are single study estimates and the error bars represent the $95 \%$ confidence intervals ( $95 \% \mathrm{Cls})$. The diamonds are pooled estimates.

IT for TB was 1.00 (95\%CI: 0.91-1.00), and the specificity of T-SPOT was 0.98 (95\% CI: 0.87-1.00). Specificity of TST resulted considerably lower $(0.58$; $95 \%$ CI: $0.42-0.73)$. The specificity of TST was 0.10 (95\% CI: $0.1-0.33$ ) in children with nontuberculous mycobacterial lymphadenitis and 1.00 (95\% CI: 0.83-1.00) in children with other nonmycobacterial respiratory tract infections. The sensitivity of both QFT-IT and T-SPOT was 0.93 (95\% CI: $0.77-$ 0.99 ), and the sensitivity of TST was 1.00 (95\% CI: $0.88-$ 1.00). Agreement between the two IGRAs was $95.6 \%$ $(\mathrm{k}=0.91)$. The authors concluded that IGRAs showed high diagnostic value in bacteriologically confirmed childhood TB and when performed in addition to TST they could be able to distinguish -positive TST results caused by nontuberculous mycobacterial disease [19]. In the same year, Okada and colleagues compared test results of QFT-G-IT and TST in 195 young children household contacts of pulmonary TB patients in Cambodia, founding considerable agreement $(k=0.63)$ between the two tests and that results were not affected by BCG vaccination in a logistic

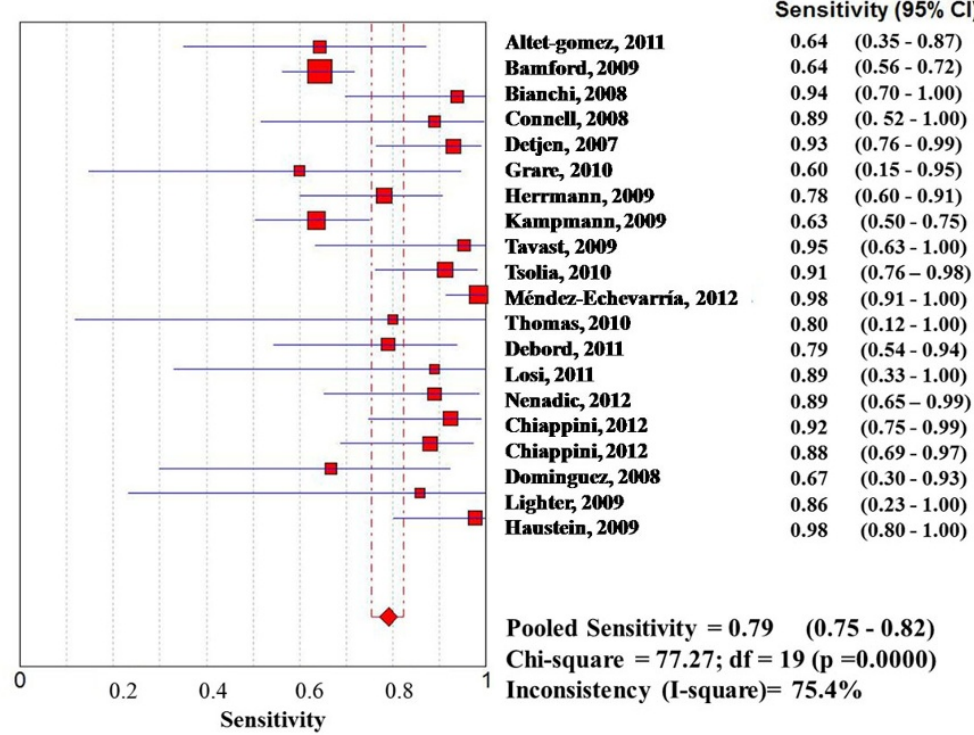

Figure 3 Forest plot of sensitivity of QuantiFERON-TB Gold In Tube (QFT-G-IT) in high-income countries. The squares are single study estimates and the error bars represent the $95 \%$ confidence intervals (95\% Cls). The diamonds are pooled estimates. 


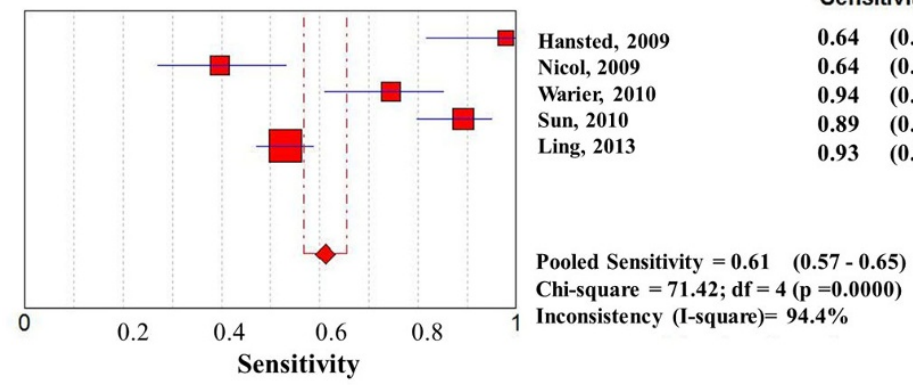

Figure 4 Forest plot of sensitivity of T-SPOT.TB in low-income countries. The squares are single study estimates and the error bars represent the $95 \%$ confidence intervals $(95 \% \mathrm{Cls})$. The diamonds are pooled estimates.

regression analysis [42]. The authors suggested QFT-G-IT may be a substitute for TST in detecting latent TB infection in childhood contacts aged $\leq 5$ years, especially in those who may have a false-positive TST due to BCG vaccination or non-tuberculous mycobacterial infection [42].

Debord and colleagues evaluated QFT-G-IT performance restrospectively in 19 French immunocompetent children (median age: 1.52 years) with active tuberculosis [28]. The rate of indeterminate results was $0 / 19$ and the rates of positivity were $6 / 10$ and $9 / 9$ in $<2$ and 2 - to 5 year-old children, suggesting QFT-G-IT could be a useful tool to improve diagnosis of tuberculosis in association to TST even in young children [29]. In the study conducted by Moyo and colleagues including 397 South African children aged less than 3 years, QFT-G-IT and TST showed notable agreement $(k=0.79)$, however, both tests had low sensitivity for TB disease (38\% and 35\%) [30]. On contrast, Pavic and colleagues found in 142 Croatian children aged $<5$ years significant discordance between QFT-G-IT and TST $(\mathrm{k}=0.59)$, concluding that both tests should be performed in high-risk children aged $<5$ years, considering the child infected if either or both tests are positive [59]. Nkurunungi and colleagues found in their cross-sectional study conducted on 907 children screened for LTBI in a high prevalence African setting that T-SPOT.TB results were unstable over a three-week follow-up interval, and that TST compares poorly with T-SPOT.TB, making the categorisation of children as TB-infected or TB-uninfected difficult [60].

Although, in general, results in young children were encouraging, a specific meta-analysis for this subjects, could not be performed as complete data were not available in most studies, except for Detjen et al. 's study [19].

\section{Discussion}

Data on IGRAs' performance in children are accumulating. In previous meta-analyses, similarly to data reported in adults, higher IGRA specificity with respect to TST has been reported. However, the reported IGRA sensitivity ranged between $62 \%$ and $89 \%$ for T-SPOT.TB and $66 \%$

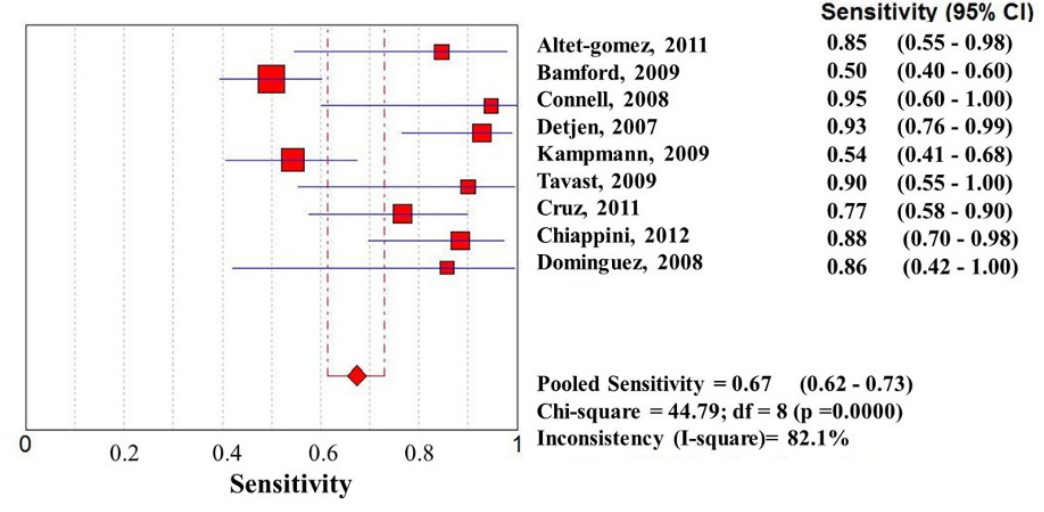

Figure 5 Forest plot of sensitivity of T-SPOT.TB in high-income countries. The squares are single study estimates and the error bars represent the $95 \%$ confidence intervals $(95 \% \mathrm{Cls})$. The diamonds are pooled estimates. 


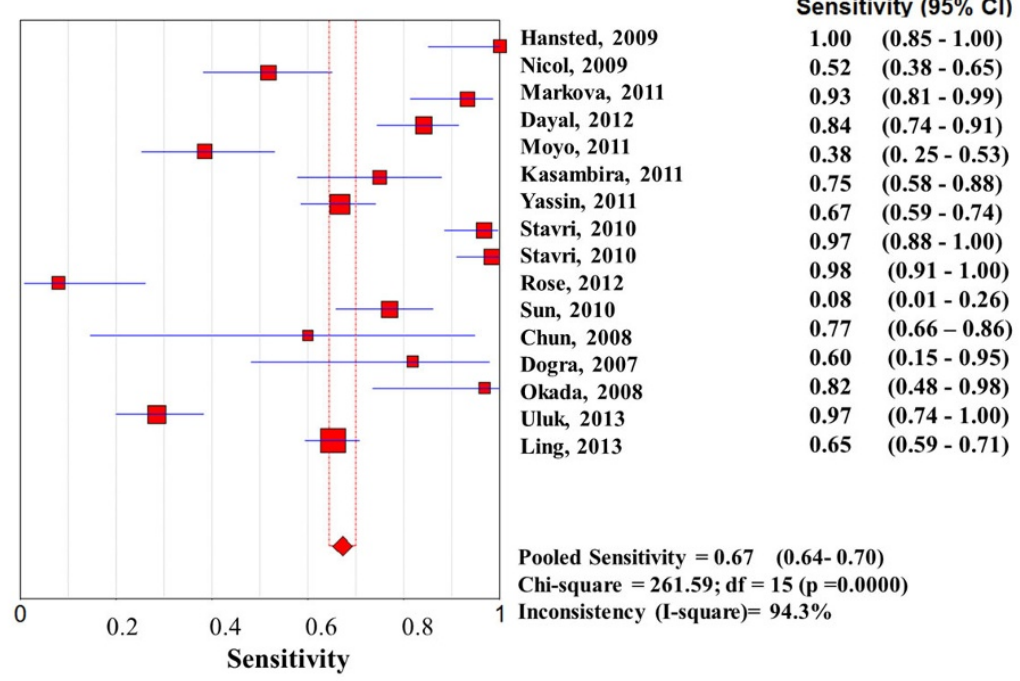

Figure 6 Forest plot of sensitivity of tuberculin skin test (TST) in low-income countries. The squares are single study estimates and the error bars represent the $95 \%$ confidence intervals (95\% Cls). The diamonds are pooled estimates.

and $83 \%$ for QFT-G-IT [1,5,9-11]. Differences between IGRA performance in low income and high income countries were evaluated only in one meta-analysis which considered only QFT-G-IT- (and not T-SPOT.TB-) based studies [1]. In that analysis, significantly lower QFT-G-IT sensitivity was observed in high-burden TB settings compared to low-burden TB settings (55\% vs. $70 \%)$. Other authors [10] performed a sub-analysis of paediatric studies by definition of TB cases and reported lower pooled sensitivity including clinical diagnoses TB cases $v s$. microbiologically confirmed TB cases (64\% vs. $85 \%$ for QFT-G-IT, $66 \%$ vs. $76 \%$ for T-SPOT.TB and $66 \%$ vs. $85 \%$ for TST) [10].

Our study is the first paediatric meta-analysis evaluating both QFT-G-IT and T-SPOT.TB performance by setting. Moreover, we were first to present a sub-analysis of studies performing a simultaneous three way comparison

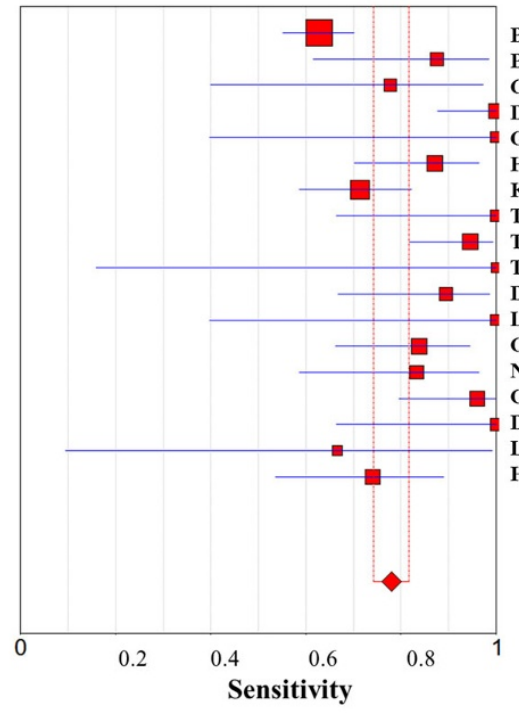

Bamford, 2009 Bianchi, 2008 Connell, 2008 Detjen, 2007 Grare, 2010

Herrmann, 2009

Kampmann, 2009 Tavast, 2009

Tsolia, 2010 Thomas, 2010

Debord, 201

osi, 2011 Cruz, 2011

Nenadic, 2012

Chiappini, 2012

Dominguez, 2008

Lighter, 2009

Haustein, 2009

Pooled Sensitivity $=0.78 \quad(0.74-0.82)$
Chi-square $=69.96 ; \mathrm{df}=17(\mathrm{p}=0.0000)$

Inconsistency $($ I-square $)=79.3 \%$

Figure 7 Forest plot of sensitivity of tuberculin skin test (TST) in high-income countries. The squares are single study estimates and the error bars represent the $95 \%$ confidence intervals (95\% Cls). The diamonds are pooled estimates. 
Table 2 Sensitivities and specificities of Interferon-gamma release assays (IGRAs) and tuberculin skin test (TST) in the present meta-analysis.

\begin{tabular}{|c|c|c|c|c|}
\hline & & TST & QFN-G-IT & T-SPOT.TB \\
\hline \multirow[t]{7}{*}{ Sensitivity } & Low income countries & $\begin{array}{l}0.67(95 \% \mathrm{Cl} 0.64-0.70) ; \\
\text { Chi-square }=261.59 ; \mathrm{df}=15 \\
(p=0.0000) \\
\text { Inconsistency (I-square) }=94.3 \%\end{array}$ & $\begin{array}{l}0.57(95 \% \mathrm{Cl} 0.52-0.61) ; \text { Chi-square }=51.04 ; \mathrm{df}=10(\mathrm{p}=0.0000) \\
\text { Inconsistency (I-square) }=80.4 \%\end{array}$ & $\begin{array}{l}0.61(95 \% \mathrm{Cl} 0.57-0.65) ; \text { Chi-square }=71.42 ; \\
\mathrm{df}=4(\mathrm{p}=0.0000) \\
\text { Inconsistency }(\text { (I-square })=94.4 \%\end{array}$ \\
\hline & High income countries & $\begin{array}{l}0.78(95 \% \mathrm{Cl} 0.74-0.82) ; \\
\text { Chi-square }=69.96 ; \mathrm{df}=17 \\
(p=0.0000) \\
\text { Inconsistency }(\text { I-square })=79.3 \%\end{array}$ & $\begin{array}{l}0.79(95 \% \mathrm{Cl} 0.75-0.82) ; \text { Chi-square }=77.27 ; \mathrm{df}=19(\mathrm{p}=0.0000) \\
\text { Inconsistency }\left(\left(^{2}\right)=75.4 \%\right.\end{array}$ & $\begin{array}{l}0.67(95 \% \mathrm{Cl} 0.62-0.73) ; \text { Chi-square }=44.79 ; \\
\mathrm{df}=8(\mathrm{p}=0.0000) \\
\text { Inconsistency (I-square) }=82.1 \%\end{array}$ \\
\hline & $\begin{array}{l}\text { Including only studies using the } \\
\text { three assays simoultaneously }\end{array}$ & $\begin{array}{l}0.85(95 \% \mathrm{Cl} 0.78-0.91) \\
\text { Chi-square }=26.01 ; \mathrm{df}=5 \\
(p=0.0001) \\
\text { Inconsistency }(\mathrm{I} \text {-square })=80.8 \%\end{array}$ & $\begin{array}{l}0.78(95 \% \mathrm{Cl} 0.70-0.84) ; \text { Chi-square }=16.85 ; \mathrm{df}=5(\mathrm{p}=0.0048) \\
\text { Inconsistency }(\mathrm{I}-\text { square })=70.3 \%\end{array}$ & $\begin{array}{l}0.76(95 \% \mathrm{Cl} 0.68-0.83) ; \text { Chi-square }=24.94 ; \\
d f=6(p=0.0001) \\
\text { Inconsistency (I-square })=80.0 \%\end{array}$ \\
\hline & $\begin{array}{l}\text { Including microbiologically } \\
\text { confirmed cases (overall) }\end{array}$ & $\begin{array}{l}0.79(95 \% \mathrm{Cl} 0.75-0.83) \\
\text { Chi-square }=41.56 ; \mathrm{df}=16 \\
(p=0.0005) \\
\text { Inconsistency (I-square) }=61.5 \%\end{array}$ & $\begin{array}{l}0.81(95 \% \mathrm{Cl} 0.76-0.85) ; \text { Chi-square }=45.51 ; \mathrm{df}=15(\mathrm{p}=0.0001) \\
\text { Inconsistency }(\text { (I-square })=67.0 \%\end{array}$ & $\begin{array}{l}0.80(95 \% \mathrm{Cl} 0.73-0.86) ; \text { Chi-square }=27.31 \\
\mathrm{df}=8(\mathrm{p}=0.0006) \\
\text { Inconsistency }(\text { (I-square })=70.7 \%\end{array}$ \\
\hline & $\begin{array}{l}\text { Including microbiologically } \\
\text { confirmed cases, in low income } \\
\text { countries }\end{array}$ & $\begin{array}{l}0.74(95 \% \mathrm{Cl} 0.68-0.80) \\
\text { Chi-square }=20.28 ; \mathrm{df}=6 \\
(\mathrm{p}=0.0025) \\
\text { Inconsistency (I-square })=70.4 \%\end{array}$ & $\begin{array}{l}0.66(95 \% \mathrm{Cl} 0.55-0.76) ; \text { Chi-square }=6.19 ; \mathrm{df}=4(\mathrm{p}=0.1857) \\
\text { Inconsistency }(\mid- \text {-square })=35.3 \%-\text { excluding studies with } \\
\text { immunocompromised children: } 0.68 \text { (95\%lC 0.57-0.79); Chi-square = } \\
3.18 ; \mathrm{df}=3(\mathrm{p}=0.3644) \\
\text { Inconsistency (I-square) }=5.7 \%\end{array}$ & $\begin{array}{l}0.80(95 \% \mathrm{Cl} 0.59-0.90) ; \text { Chi-square }=17.35 \\
\mathrm{df}=4(\mathrm{p}=0.0017) \\
\text { Inconsistency }(\text { (I-square })=76.9 \%\end{array}$ \\
\hline & $\begin{array}{l}\text { Including microbiologically } \\
\text { confirmed cases, in high income } \\
\text { countries }\end{array}$ & $\begin{array}{l}0.86(0.79-0.91) ; \text { Chi-square }= \\
14.06 ; d f=9(p=0.1203) \\
\text { Inconsistency }(\text { (-square })=36.0 \%\end{array}$ & $\begin{array}{l}0.86(0.81-0.90) ; \text { Chi-square }=25.78 ; \mathrm{df}=10(p=0.0040) \\
\text { Inconsistency }(\text { I-square })=61.2 \%\end{array}$ & $\begin{array}{l}0.79(0.69-0.87) ; \text { Chi-square }=9.90 ; d f=3 \\
(p=0.0194) \\
\text { Inconsistency }(\text { (I-square })=69.7 \%\end{array}$ \\
\hline & $\begin{array}{l}\text { Immunocompromised/HIV infected } \\
\text { children }\end{array}$ & $\begin{array}{l}0.54(95 \% \text { IC } 0.49-0.59) ; \\
\text { Chi-square }=71.45 ; d f=3(p \\
=0.0000) \\
\text { Inconsistency (I-square) }=95.8 \%\end{array}$ & $\begin{array}{l}0.47(95 \% \mathrm{Cl} 0.38-0.55) ; \text { Chi-square }=37.77 ; \mathrm{df}=2(\mathrm{p}=0.0000) \\
\text { Inconsistency (I-square })=94.7 \%\end{array}$ & Not evaluable \\
\hline \multirow[t]{4}{*}{ Specificity } & Low income countries & $\begin{array}{l}0.90(95 \% \text { IC } 0.87-0.92) ; \text { Chi- } \\
\text { square }=38.57 ; \mathrm{df}=7 \\
(p=0.0000) \\
\text { Inconsistency (I-square) }=81.9 \%\end{array}$ & $\begin{array}{l}0.85(95 \% \mathrm{Cl} 0.82-0.88) ; \text { Chi-square }=19.15 ; \mathrm{df}=5(\mathrm{p}=0.0018) \\
\text { Inconsistency }(\mathrm{I} \text {-square })=73.9 \%\end{array}$ & $\begin{array}{l}0.93(95 \% \mathrm{Cl} 0.87-0.96) ; \text { Chi-square }=7.75 \\
\mathrm{df}=2(\mathrm{p}=0.0207) \\
\text { Inconsistency }(\text { (I-square })=74.2 \%\end{array}$ \\
\hline & High income countries & $\begin{array}{l}0.92(95 \% \mathrm{Cl} 0.89-0.93) ; \\
\text { Chi-square }=125.84 ; \mathrm{df}=10 \\
(\mathrm{p}=0.0000) \\
\text { Inconsistency }(\mathrm{I} \text {-square })=92.8 \%\end{array}$ & $\begin{array}{l}0.97(95 \% \mathrm{Cl} 0.96-0.98) ; \text { Chi-square }=38.83 ; \mathrm{df}=10(\mathrm{p}=0.0000) \\
\text { Inconsistency }(\text { (I-square })=74.2 \%\end{array}$ & $\begin{array}{l}0.98(95 \% \mathrm{Cl} 0.96-0.99) ; \text { Chi-square }=12.98 ; \\
d f=5(p=0.0235) \\
\text { Inconsistency (I-square })=61.5 \%\end{array}$ \\
\hline & $\begin{array}{l}\text { Including only studies using the } \\
\text { three assays simoultaneously (all in } \\
\text { high income countries) }\end{array}$ & $\begin{array}{l}0.84(95 \% \mathrm{Cl} 0.79-0.89) \\
\text { Chi-square }=74.74 ; \mathrm{df}=4 \\
(p=0.0000) \\
\text { Inconsistency }(\text { I-square })=94.6 \%\end{array}$ & $\begin{array}{l}0.97(95 \% \mathrm{Cl} 0.93-0.99) ; \text { Chi-square }=6.05 ; \mathrm{df}=3(\mathrm{p}=0.1093) \\
\text { Inconsistency (I-square) }=50.4 \%\end{array}$ & $\begin{array}{l}0.97(95 \% \mathrm{Cl} 0.93-0.99) ; \text { Chi-square }=8.47 ; \mathrm{d} \\
=3(p=0.0373) \\
\text { Inconsistency (I-square) }=64.6 \%\end{array}$ \\
\hline & $\begin{array}{l}\text { Immunocompromised/HIV infected } \\
\text { children }\end{array}$ & $\begin{array}{l}0.97(0.92-0.99) ; \text { Chi-square }= \\
0.95 ; d f=1(p=0.0000) \\
\text { Inconsistency (I-square) }=0.0 \% \\
\text { Chi-square = } 0.95 ; d f=1 \\
(p=0.0000) \\
\text { Inconsistency (I-square) }=0.0 \%\end{array}$ & $\begin{array}{l}0.90(95 \% \mathrm{Cl} 0.81-0.95) ; \text { Chi-square }=0.00 ; \mathrm{df}=1(\mathrm{p}=0.9695) \\
\text { Inconsistency }(\text { I-square })=0.0 \%-\text { only } 2 \text { studies could be included - }\end{array}$ & Not evaluable \\
\hline
\end{tabular}


using all the tests in the same child, allowing to reduce potential bias due to individual differences.

At a first glance, our meta-analytic results showed a higher sensitivity of QFT-G-IT than TST in high income countries (79\% vs. $75 \%$ ), where T-SPOT.TB seems to have lower sensitivity than the two other tests (67\%). However this result was not confirmed including only ascertained cases, with a microbiological confirmation. In this sub-analysis T-SPOT.TB sensitivity reached $80 \%$ (95\%CI: 59-90) while QFT-G-IT sensitivity decreased, but not significantly, to $66 \%$ (95\%CI:55-76). This finding suggests caution when interpreting results from studies including probable and ascertained TB cases in children, for possible misdiagnoses.

In a further sub-analysis including only studies performing simultaneously the 3 tests, all performed in high income countries, overall including 618 children, no different sensitivity of both IGRAs and TST was observed, while a higher IGRAs specifity was confirmed (97\% vs. 84\%).

Very low sensitivity and specificity were found in the sub-analysis performed with studies in immunocompromised children. The meta-analytic estimate for sensitivity was only 0.54 for TST, and 0.47 for QFT-G-IT, confirming that IGRA results should be still interpreted with caution in immunocompromised children.

Combining all these results, both IGRAs seem to be a reasonable choice in the diagnosis of TB disease in immunocompetent children aged $>5$ years in high income countries. In low income-countries and in immunocompromised children IGRAs' performance is equivalent or inferior to TST. Considerations regarding costs, availability for clinicians and other health workers, patient acceptability, ease of distribution and storage should also be taken into account in this kind of setting. To date, data in the paediatric population aged less than 5 years are limited, and a specific sub-analysis for this category of studies could not be performed as complete data were not evincible from the considered studies $[19,28,30,42,59,60]$.

\section{Conclusions}

In conclusion IGRAs show good promise for improving TB diagnosis only in immunocompetent children aged $>5$ years in high income setting. Even in these subjects, however, IGRAs sensitivity was $67-86 \%$, indicating that neither test may rule out nor confirm the certainty of diagnosis and, similarly to the TST, interpretation of results may be difficult. As recently recommended by the NICE guidelines [13], paediatricians while deciding who deserves antitubercular therapy, still have to consider clinical and epidemiological data. Some authors suggest that the combined use of TST and IGRAs might help clinicians by increasing the diagnostic sensitivity to $90 \%$, however interpretation of discordant results is controversial [19].

\section{Additional material}

Additional file 1: Appendix Contents: Appendix 1: Search strategy Appendix 2: Studies excluded from the meta-analysis and main exclusion criteria. Appendix 3: Quality assessment of the studies included in the meta-analysis. Appendix 4: Individual-study and pooled estimates for sensitivity, specificity, and summary of the study characteristics. Appendix 5: T-SPOT.TB ${ }^{{ }_{\circledast}}$, QuantiFERON ${ }^{{ }}{ }_{-}$TB Gold In tube and tuberculin skin test data in microbiologically confirmed active tuberculosis cases among the studies included in the sub-analysis to calculate meta-analytic estimates for sensitivity. Appendix 6: Summary of results from relevant studies on Interferon- $\gamma$ release assays (IGRAs) in children.

\section{Competing interests}

All authors declare to have no conflicts of interest.

\section{Authors' contributions}

EC and SS participated in data collection and data analysis. LG and MdM supervised the work. All authors participated in the study design and in writing of the manuscript. EC and SS performed the meta-analysis. All authors approved the final manuscript.

\section{Declarations}

Funding for this article has come from the Italian Health Ministry /Young Research Project.

This article has been published as part of BMC Infectious Diseases Volume 14 Supplement 1, 2014: Highlights in Pediatric Tuberculosis. The full contents of the supplement are available online at http://www.biomedcentral.com/ bmcinfectdis/supplements/14/S1

Published: 8 January 2014

\section{References}

1. Machingaidze S, Wiysonge CS, Gonzalez-Angulo Y, Hatherill M, Moyo S, Hanekom W, Mahomed H: The utility of an Interferon Gamma release assay for diagnosis of latent tuberculosis infection and disease in children: a systematic review and meta-analysis. Pediatr Infect Dis J 2011, 30:694-700.

2. Maruzek GH, Goldberg S, Jereb JA, Vernon AN, LoBue PA, Castro KG: Updated guidelines for using interferon gamma release assays to detect Mycobacterium tuberculosis infection. 2010, 59(RR05):1-25, Available at: http://www.cdc.gov/mmWr/preview/mmwrhtml/rr5905a1.htm.

3. Haustein T, Ridout D, Hartley JC, Thaker U, Shingadia D, Klein NJ, Novelli V, Dixon GLJ: The likelihood of an indeterminate test result from a wholeblood interferon- $\gamma$ release assay for the diagnosis of Mycobacterium tuberculosis infection in children correlates with age and immune status. Paediatr Infect Dis J 2009, 28:669-673.

4. Lalvani A, Millington KA: T-cell-based diagnosis of childhood tuberculosis infection. Curr Opin Infect Dis 2007, 20:264-271.

5. Menzies D, Madhukar P, Comstock G, et al: Meta-analysis: new tests for the diagnosis of latent tuberculosis infection: areas of uncertainty and recommendations for research. Ann Intern Med 2007, 146:340-354.

6. Pai M, Zewerling A, Menzies D: Systematic review: T-cell-based assays for the diagnosis of latent tuberculosis infection: an update. Ann Intern Med 2008, 149:177-184

7. Dheda K, van Zyl Smith R, Badri M, Pai M: T-cell interferon- $\gamma$ release assays for the rapid immunodiagnosis of tuberculosis: clinical utility in high-burden vs. Low-burden settings. Curr Opin Pulm Med 2009, 15:188-200.

8. Diel R, Loddenkemper R, Nienhaus A: Evidence based comparison of commercial interferon-gamma release assays for detecting active tuberculosis- a meta-analysis. Chest 2010, 137:952-968.

9. Mandalakas AM, Detjen AK, Hesseling AC, Benedetti A, Menzies D: Interferon-gamma release assays and childhood tuberculosis: systematic review and meta-analysis. Int J Tuberc Dis 2011, 15:1018-1032.

10. Sun L, Xiao J, Miao Q, Feng W, Wu X, Yin Q, Jiao W, Shen C, Liu F, Shen D, Shen $A$ : Interferon gamma release assay in diagnosis of pediatric tuberculosis: a meta-analysis. FEMS Immunol Med Microbiol 2011, 63:165-173. 
11. Chiappini E, Accetta G, Bonsignori F, Boddi V, Galli L, Biggeri A, De Martino M: Interferon- $\gamma$ release assays for the diagnosis of Mycobacterium tuberculosis infection in children: a systematic review and meta-analysis. Int J Immunopathol Pharmacol 2012, 25:557-564.

12. Sester $M$, Sotgiu $G$, Lange $C$, et al: Interferon-\{gamma\} release assays for the diagnosis of active tuberculosis: A systematic review and metaanalysis. Eur Respir J 2011, 37:100-111.

13. NICE Guideline CG117: Tuberculosis. Clinical management and diagnosis of tuberculosis, and measures for its prevention and control 2011.

14. Bamford ARJ, Crook MA, Clark J, et al: Comparison interferon-gamma release assays and tuberculin skin test in predicting active tuberculosis (TB) in children in the UK-a Paediatric TB Network Study. ArchDis Child 2010, 95:180-186.

15. Zamora J, Abraira V, Muriel A, Khan K, Coomarasamy A: Meta-DiSc: a software for meta-analysis of test accuracy data. BMC Med Res Methodol 2006, 6:31, [PMID: 16836745].

16. Altet-Gómez N, De Souza-Galvao M, Latorre I, Milà C, Jiménez MA, Solsona J, Cantos A, Zamora JJ, Ruiz-Manzano J, Ausina V, Domínguez J: Diagnosing TB infection in children: analysis of discordances using in vitro tests and the tuberculin skin test. Eur Respir J 2011, 37:1166-1174.

17. Bianchi $L$, Galli $L$, Moriondo $M$, et al: Interferon- $\gamma$ release assay improves the diagnosis of tuberculosis in children. Ped Infect Dis J 2009, 28:510-514.

18. Connell TG, Ritz N, Paxton GA, et al: A three-way comparison of tuberculin skin testing, quantiFERON-TB Gold and T-SPOT.TB in children. PLOS ONE 2008, 3:e2624.

19. Detjen AK, Keil T, Roll $S$, et al: Interferon- $\gamma$ release assay improve the diagnosis of tuberculosis and nontuberculous mycobacterial disease in children in a country with a low incidence of tuberculosis. Clin Infect Dis 2007, 45:322-328.

20. Grare M, Derelle J, Dailloux M, et al: QuantiFERON-TB Gold In-Tube as help for the diagnosis of tuberculosis in a French paediatric hospital. DiagnMicrobiol Infect Dis 2010, 66:366-372.

21. Herrmann JL, Belloy M, Porcher R, et al: Temporal dynamics of interferon gamma responses in children evaluated for tuberculosis. PLOS ONE 2009, 4:e4130.

22. Kampmann B, Whittaker $\mathrm{E}$, Williams $\mathrm{A}$, et al: Interferon- $\gamma$ release assay do not identify more children with active tuberculosis than the tuberculin skin test. EurRespir J 2009, 33:1374-1382.

23. Tavast E, Salo E, Seppala I, et al: IGRA tests perform similarly to TST but cause no adverse reactions: paediatric experience in Finland. BMC Res Notes 2009, 2:1-9.

24. Tsolia MN, Mavrikou M, Critselis $E$, et al: Whole blood interferon- $\gamma$ release assay is a useful tool fort eh diagnosis of tuberculosis infection particularly among BacilleCalmette Guerin-vaccinated children. Paediatr Infect Dis J 2010, 29:1137-1140.

25. Thomas TA, Mondal D, Noor Z, Liu L, Alam L, et al: Malnutrition and Helminth Infection Affect Performance of an Interferon \{gamma\}-Release Assay. Paediatrics 2010, 126:e1522-e1529.

26. Markova R, Drenska R, Minchev P, Todorova Y, Ciccozzi M, Amicosante M: Association of age with the level of response in the QuantiFERON-TB Gold In-Tube assay for children with active tuberculosis. New Microbiol 2011, 34:81-85.

27. Dayal R, Verma V, Sharma B, Kumar G, Kumar N, Gupta R, Katoch VM, Joshi B, Chauhan DS: Diagnostic value of interferon- gamma release assays (QuantiFERON-TB Gold ${ }^{\oplus}$ In Tube) in childhood tuberculosis. Indian J Pediatr 2012, 79:183-187.

28. Debord C, De Lauzanne A, Gourgouillon N, Guérin-El Khourouj V, Pédron B, Gaudelus J, Faye A, Sterkers G: Interferon-gamma release assay performance for diagnosing tuberculosis disease in 0- to 5-year-old children. Pediatr Infect Dis J 2011, 30:995-997.

29. Losi M, Bocchino M, Matarese A, Bellofiore B, Roversi P, Rumpianesi F, Alma MG, Chiaradonna P, Del Giovane C, Altieri AM, Richeldi L, Sanduzzi A: Role of the quantiferon-TB test in ruling out pleural tuberculosis: a multi-centre study. Int J Immunopathol Pharmacol 2011, 24:159-165.

30. Moyo S, Isaacs F, Gelderbloem S, Verver S, Hawkridge AJ, Hatherill M, Tameris M, Geldenhuys H, Workman L, Pai M, Hussey G, Hanekom WA, Mahomed $\mathrm{H}$ : Tuberculin skin test and QuantiFERON ${ }^{\circledR}$ assay in young children investigated for tuberculosis in South Africa. Int J Tuberc Lung Dis 2011, 15:1176-1181.

31. Kasambira TS, Shah M, Adrian PV, Holshouser M, Madhi SA, Chaisson RE, Martinson NA, Dorman SE: QuantiFERON-TB Gold In-Tube for the detection of Mycobacterium tuberculosis infection in children with household tuberculosis contact. Int J Tuberc Lung Dis 2011, 15:628-634

32. Yassin MA, Petrucci R, Garie KT, Harper G, Arbide I, Aschalew M, Merid Y, Kebede Z, Bawazir AA, Abuamer NM, Cuevas LE: Can interferon-gamma or interferon-gamma-induced-protein-10 differentiate tuberculosis infection and disease in children of high endemic areas? PLoS One 2011, 6:e23733.

33. Stavri HR, Murgoci G, Ulea I, Popa LG, Popa M: Prospective Comparison of Two Brands of Tuberculin Skin Tests and Quantiferon-TB Gold in-tube Assay Performances for Tuberculosis Infection in Hospitalized Children. Maedica (Buchar) 2010, 5:271-276.

34. Rose MV, Kimaro G, Nissen TN, Kroidl I, Hoelscher M, Bygbjerg IC, Mfinanga SG, Ravn P: QuantiFERON ${ }^{\circledR}$-TB gold in-tube performance for diagnosing active tuberculosis in children and adults in a high burden setting. PLoS One 2012, 7:e37851.

35. Nenadić N, Kirin BK, Letoja IZ, Plavec D, Topić RZ, Dodig S: Serial interferon- $\gamma$ release assay in children with latent tuberculosis infection and children with tuberculosis. Pediatr Pulmonol 2012, 47:401-408.

36. Chiappini E, Bonsignori F, Mangone G, Galli L, Mazzantini R, Sollai S, Azzari C, de Martino M: Serial T-SPOT.TB and quantiFERON-TB-Gold InTube assays to monitor response to antitubercular treatment in Italian children with active or latent tuberculosis infection. Pediatr Infect Dis $J$ 2012, 31:974-977.

37. Chiappini E, Della Bella C, Bonsignori F, Sollai S, Amedei A, Galli L Niccolai E, Del Prete G, Singh M, D'Elios MM, de Martino M: Potential role of $M$. tuberculosis specific IFN- $\gamma$ and IL-2 ELISPOT assays in discriminating children with active or latent tuberculosis. PLOS One 2012, 9:e46041.

38. Chun JK, Kim Ki C, Kim HS, et al: The role of a whole blood interferon- $\gamma$ assay for detection of latent tuberculosis infection in Bacille CalmetteGuèrin vaccinated children. Diagnostic microbiology and Infectious Disease 2008, 62:389-394.

39. Domínguez J, Ruiz-Manzano J, De Souza-Galvão M, Latorre I, Milà C, Blanco S, Jiménez MA, Prat C, Lacoma A, Altet N, Ausina V: Comparison of two commercially available gamma interferon blood tests for immunodiagnosis of tuberculosis. Clin Vaccine Immunol 2008, 15:168-171.

40. Dogra S, Narang P, Mendiratta DK, et al: Comparison of a whole blood interferon- $\gamma$ assay with tuberculin skin testing for the detection of tuberculosis infection in hospitalize children in rural India. J Infect 2007, 54:267-276.

41. Lighter J, Rigaud M, Eduardo R, et al: Latent tuberculosis diagnosis in children by using the QuantiFERON-TB Gold in-Tube test. Paediatrics 2009, 123:30-37.

42. Okada K, Mao TE, Mori T, et al: Performance of an interferon-gamma release assay for diagnosing latent tuberculosis infection in children. Epidemiol Infect 2008, 136:1179-1187.

43. Uluk T, Allison WE, Vince J, Wand H, Tefuarani N, Causer LM, Ripa P, Kariko M, Kaminiel O, Cunningham P, Graham SM, Kaldor JM: Evaluation of an interferon-gamma release assay in children with suspected tuberculosis in Papua New Guinea. Pediatr Infect Dis J 2013, 32:187-189.

44. Méndez-Echevarría A, González-Muñoz M, Mellado MJ, Baquero-Artigao F, Vecino R, Pérez E, Spanish Collaborative Group for the Study of QuantiFERON-TB GOLD Test in Children: Interferon- $\gamma$ release assay for the diagnosis of tuberculosis in children. Arch Dis Child 2012, 97:514-516.

45. Nicol MP, Davies MA, Wood K, et al: Comparison of T-SPOT.TB assay and tuberculosis skin tests for the evaluation of young children at high risk for tuberculosis in a community setting. Paediatrics 2009, 123:38-43.

46. Cruz AT, Geltemeyer AM, Starke JR, Flores JA, Graviss EA, Smith KC: Comparing the tuberculin skin test and T-SPOT.TB blood test in children. Pediatrics 2011, 127:e31-38.

47. Hansted E, Andriuskeviciene, Sakalauskas R, et al: T-cell-based diagnosis of tuberculosis infection in children in Lithuania: a country of high incidence despite a high coverage with bacilli Calmette-Guerin vaccination. BMC Pulmonary Medicine 2009, 9:41.

48. Warier A, Gunawathi S, Venkatesh, John KR, Bose A: T-cell assay as a diagnostic tool for tuberculosis. Indian Pediatr 2010, 47:90-92.

49. Sun L, Yan HM, Hu YH, Jiao WW, Gu Y, Xiao J, Li HM, Jiao AX, Guo YJ, Shen AD: IFN- $\gamma$ release assay: a diagnostic assistance tool of tuberculin skin test in pediatric tuberculosis in China. Chin Med J (Engl) 2010, 123:2786-2791.

50. Ling DI, Nicol MP, Pai M, Pienaar S, Dendukuri N, Zar HJ: Incremental value of T-SPOT.TB for diagnosis of active pulmonary tuberculosis in children in a high-burden setting: a multivariable analysis. Thorax 2013, 68:860-866. 
51. Noorbakhsh S, Mousavi J, Barati M, Shamshiri AR, Shekarabi M, Tabatabaei A, Soleimani M: Evaluation of an interferon-gamma release assay in young contacts of active tuberculosis cases. East Mediterr Health J 2011, 17:714-718.

52. Liebeschuetz S, Bamber S, Deeks J, et al: Diagnosis of tuberculosis in South African children with a T-cell-based assay: a prospective cohort study. Lancet 2004, 364:2196-2203.

53. Bruzzese $E$, Bocchino $M$, Assante $L R$, et al: Gamma interferon release assays for detection of tuberculosis infection in immune-compromised children in a country in which the prevalence of tuberculosis is low. J Clin Microbiol 2009, 47:2355-2357.

54. Stefan DC, Dippenaar A, Detjen AK, et al: Interferon-gamma release assay for the detection of Mycobacterium tuberculosis infection in children with cancer. Int J Tuberc Lung Dis 2010, 14:689-694.

55. Davies MA, Connell T, Johannisen C, Wood K, Pienaar S, Wilkinson KA, Wilkinson RJ, Zar HJ, Eley B, Beatty D, Curtis N, Nicol MP: Detection of tuberculosis in HIV-infected children using an enzyme-linked immunospot assay. AIDS 2009, 23:961-969.

56. Mandalakas AM, Hesseling AC, Chegou NN, et al: High level of discordant IGRA results in HIV-infected adults and children. Int J Tuberc Lung Dis 2008, 12:417-423.

57. Mandalakas AM, van Wyk S, Kirchner HL, Walzl G, Cotton M, Rabie H, Kriel B, Gie RP, Schaaf HS, Hesseling AC: Detecting tuberculosis infection in HIVinfected children: a study of diagnostic accuracy, confounding and interaction. Pediatr Infect Dis J 2013, 32:e111-8.

58. Connell TG, Davies MA, Johannisen $C$, et al: Reversion and conversion of Mycobacterium tuberculosis IFN-gamma ELISpot results during antituberculous treatment in HIV-infected children. BMC Infect Dis 2010, 10:138.

59. Pavić I, Zrinski Topić R, Raos M, Aberle N, Dodig S: Interferon- $\gamma$ release assay for the diagnosis of latent tuberculosis in children younger than 5 years of age. Pediatr Infect Dis J 2011, 30:866-870.

60. Nkurunungi $\mathrm{G}$, Lutangira JE, Lule SA, Akurut $\mathrm{H}$, Kizindo R, Fitchett JR, Kizito D, Sebina I, Muhangi L, Webb EL, Cose S, Elliott AM: Determining Mycobacterium tuberculosis infection among BCG-immunised Ugandan children by T-SPOT.TB and tuberculin skin testing. PLOS One 2012, 10 e47340.

doi:10.1186/1471-2334-14-S1-S6

Cite this article as: Sollai et al:: Systematic review and meta-analysis on the utility of Interferon-gamma release assays for the diagnosis of Mycobacterium tuberculosis infection in children: a 2013 update. BMC Infectious Diseases 2014 14(Suppl 1):S6.

\section{Submit your next manuscript to BioMed Central and take full advantage of:}

- Convenient online submission

- Thorough peer review

- No space constraints or color figure charges

- Immediate publication on acceptance

- Inclusion in PubMed, CAS, Scopus and Google Scholar

- Research which is freely available for redistribution

Submit your manuscript at www.biomedcentral.com/submit
Biomed Central 